\title{
Jiang Rong, Le Totem du loup, (Wolf Totem) translated by Yan Hansheng and Lisa Carducci
}

Paris, Bourin Editeur, 2007, 576 pp.

\section{Noël Dutrait}

\section{OpenEdition}

\section{Journals}

Electronic version

URL: http://journals.openedition.org/chinaperspectives/4825

DOI: $10.4000 /$ chinaperspectives. 4825

ISSN: 1996-4617

\section{Publisher}

Centre d'étude français sur la Chine contemporaine

Printed version

Date of publication: 1 June 2009

Number of pages: $125-127$

ISSN: 2070-3449

\section{Electronic reference}

Noël Dutrait, « Jiang Rong, Le Totem du loup, (Wolf Totem) translated by Yan Hansheng and Lisa Carducci », China Perspectives [Online], 2009/2 | 2009, Online since 01 June 2009, connection on 22

September 2020. URL : http://journals.openedition.org/chinaperspectives/4825 ; DOI : https://doi.org/ 10.4000/chinaperspectives.4825

This text was automatically generated on 22 September 2020 .

(C) All rights reserved 


\title{
Jiang Rong, Le Totem du loup, (Wolf Totem) translated by Yan Hansheng and Lisa Carducci
}

Paris, Bourin Editeur, 2007, 576 pp.

\author{
Noël Dutrait
}

1 Published in China in 2004 by Changjiang wenyi chubanshe, Jiang Rong's novel Lang tuteng (Wolf Totem) was immediately a phenomenal success. I myself witnessed this success while in China, where bookshops displayed multiple stacks of the book. Its author, Jiang Rong, the pseudonym of Lu Jiamin, was an activist in the Tiananmen Square movement in 1989; now a researcher in social sciences and the husband of Zhang Kangkang, a well-known writer, Jiang Rong maintained a mystery surrounding his identity, refusing to give interviews for several months. Having lived in Inner Mongolia for 11 years as a young scholar before becoming a researcher and teacher of political science in Beijing, Jiang Rong spent 20 years writing his conception of the history of China and its relations with the Mongols in the form of an eyewitness report and of a novel.

2 As soon as it was published, the book generated controversy. To many Chinese the thesis presented is unacceptable: the Mongols, a nomadic people who follow the Spirit of the Wolf, came to dominate the world, whereas the Chinese, an agricultural people who believed in the Spirit of the Sheep, were unable to resist foreign invasion and had to submit to oppression by the beginning of the nineteenth century. Naturally, one could deduce from this that if the Chinese managed to draw inspiration from this "Spirit of the Wolf," a glorious future would lie before them. This is what the CEO of Hai'er, Zhang Ruimin, is quoted as saying on the back cover of the book: "After reading Wolf Totem, I understood that it was worth borrowing many of the fighting methods used by wolves: not engaging without preparation, knowing how to choose the best moment to strike, attacking by surprise..." Some criticized the novel's historical inaccuracies, while others sensed strong whiffs of nationalism and even calls for militarism. But, as pointed out by Pascale Nivelle in an article in Libération when the 
French translation was published in 2007, the biggest surprise was the interest shown in the novel in economic circles, which according to Nivelle turned it into "the Bible of Chinese freemarketeers." ${ }^{1}$

3 The French translation is credited to Yan Hansheng and Lisa Carducci, with a puzzling mention made that "the French edition was established by Boris Martin," without indicating what this editorial work entailed. The back cover presents the book to the French public as "a fascinating adventure novel," the "story of an initiation, that of Chen Zhen, a young Chinese student, who has to learn from the Mongol tribes how to survive..." Although lower down it says that "like his hero Chen Zhen, Jiang Rong spent eleven years in the Steppe during the Cultural Revolution in the company of the Mongols and the wolves," a French reader could expect this to be merely an adventure novel, given the toning down of the philosophical dimension and the context of the Cultural Revolution.

4 The book was given a glowing reception in the French press. Several articles emphasised that the novel had won the first Man Asian Literary Prize, and that the rights had been sold in 24 countries. These rights were expensive, with the French publisher paying 50,000 euros to acquire them. As happens only rarely in French publishing, the publisher set up a website dedicated to the book, http:// www.letotemduloup.fr, where one finds an introduction to the author and an interview with him, various newspaper articles, and all sorts of information about the book, and one can even, by clicking in the right place, hear a wolf howl!

In Le Monde, Alain Beuve-Méry wrote: "Wolf Totem was highly successful in China because it immediately set off heated debate over its highly subversive content. It set off a great deal of debate on the Internet. It was praised by businessmen, intellectuals, teachers of literature, journalists, and the wider public, but it was also the target of violent attacks from defenders of Confucianism, extreme nationalists, and supporters of the conservative wing of the CCP, who demanded that it be banned - and are still demanding that, even though the novel is in libraries and is even the subject of doctoral theses." Beuve-Méry then went on to describe the book as "a philosophical novel with autobiographical content that can be read on several levels. The setting is Inner Mongolia. The main character discovers and feels himself drawn to the culture of the Mongol people, who love freedom and whose totem is the Wolf. 'As long as the Chinese people behave like sheep, the Dragon (which is the symbol of authority) will have a quiet life,' Jiang Rong explained in an interview with The New York Times in November 2005: this is why he exhorts his compatriots to change into wolves.“2

6 In the United States, some reviews were more negative. In the 4 May 2008 edition of The New York Times, Pankaj Mishra concluded his article as follows: "It seems strange that the Chinese censors missed this indictment of Han imperialism. It's even more remarkable that a novel so relentlessly gloomy and ponderously didactic has become a huge best seller, second in circulation only to Mao's little red book. This success may be due, at least in part, to its exhortations to the Chinese to imitate the go-getting spirit of the West. However, Wolf Totem also captures a widespread Chinese anxiety about their country's growing physical and moral squalor as millions abandon the countryside in search of a middleclass lifestyle that cannot be environmentally sustained. The novel's literary claims are shaky; and Jiang Rong's apparent wish to transform China's national character through a benign conservationism is compromised by his boy-scoutish arguments for toughness. Yet few books about today's China can match Wolf Totem as a 
guide to the troubled self-images of so many of its people as they stumble, grappling with some inconvenient truths of their own, into modernity." ${ }^{3}$

Ultimately, with the benefit of hindsight, how can we perceive this novel, a very unusual one in the literary world of the early twenty-first century dominated by established novelists such as Yu Hua, Mo Yan, Han Shaogong, Yan Lianke, and many others?

8 The first important point, it seems to me, is the fact that a Chinese from the Han ethnic majority is asking questions of a philosophical, historical, and ethical nature about an ethnic minority, the Mongols, not only without contempt, but with admiration. Other ethnic minority writers have glorified their past and their way of living (for example Zhang Chengzhi), but as far as I know, very few Han writers have devoted a whole book to an ethnic minority without condescension or exoticism. To reinforce the historical credibility of the novel and of the analysis he puts forward, the author heads each chapter with a quotation from a major Chinese historian (Sima Qian, Fan Wenlan, The Book of the Han, The Book of the Wei) and even Western works, as in Chapter 20, where he quotes René Gousset's L'Empire des Steppes: “The horsemen of my father the Great Khan were as brave as wolves, whereas our enemies were as cowardly as sheep."

9 Secondly, some passages in the novel possess an undeniable narrative power that must have entranced Chinese readers. For example Chapter 5 , in which wolves and horses are in combat, or Chapter 33, which describes the death of a wolf cub that moved many readers to tears. However, one is sometimes confounded by the naivety of certain remarks about the behaviour of wolves as analysed by the novel's hero. In Chapter 14 one reads this about a little wolf that the hero has captured in its lair and which he is raising in order to study its behaviour: "To the wolf cub life was as precious as freedom: he wanted both of them! One sometimes finds this strength of soul among humans, like the revolutionaries who fell into the hands of the Kuomintang or of the Americans, but these militants made up only a small elite of the Chinese nation. Among the wolves, it was a permanent, general quality transmitted from generation to generation. It had also been transmitted to the Mongol people, who had made the Wolf their Totem,

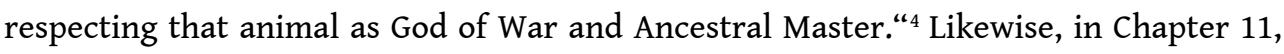
an analysis of an "ethnological" kind gives the reader pause: "Westerners eat with a knife and fork, devour rare beef, consume cheese and butter. That is why they have kept a lot of their primitive, animal nature, much more so than agricultural peoples." ${ }^{5}$ We note in passing that that the word "rare" does not appear in the original text, but was added by the translators. One could point to many other examples of this kind, which make reading this novel considerably more cumbersome.

Lastly, the ecological aspect of the novel is certainly part of the reason for its success. The descriptions of the endless steppes and the destructive changes being imposed on them cannot have failed to touch both Chinese and Western readers. The damage being done to the ecological system in the Mongolian steppes is referred to again and again, highlighting the wisdom of the elders, who have always known that wolves must not be killed in excessive numbers because they live on the rats, who devastate the steppes when they are too numerous.

11 Certain scenes in this novel are unforgettable. The battles between wolves and horses are particularly well described, as are the mosquito attacks on men and dogs, which nearly drive them mad. ${ }^{6}$ Yet one sometimes gets the impression that this book is already out of date. China's dazzling development over the last 30 years negates the 
author's theory that his country, inhabited by farmers sustained by the Spirit of the Sheep, would never become strong until it adopted the Spirit of the Wolf. Or is this development, in fact, precisely due to a profound change in mentality that proves the author right? Following this reasoning, some fear that the "Spirit of the Wolf" may lead today's China to develop an expansionist spirit, like that of the Mongol Empire. This is no doubt why the German sinologist Wolfgang Kubin has accused the author of serving as a vehicle for "fascist" ideas, even though Jiang Rong has declared, "I emphasise the positive aspects of the wolf: his esprit de corps, his attachment to freedom and strength. These are the characteristics that will impose democracy on China. It is because we are sheep that the dictatorship endures."

Translated by Michael Black

\section{NOTES}

1. Pascale Nivelle, “L'Année du loup,“ Libération, “Livres” supplement, 7 February 2008, p. II-III.

2. See Alain Beuve-Méry, "L'offensive mondiale du Totem du loup“, Le Monde des livres, 11 January 2008.

3. Pankag Mishra, "Call of the Wild, The New York Times, 4 May 2008, http:// www.nytimes.com/2008/05/04/ books/review/Mishra-t.html?_r=2\&oref=slogin, accessed 20 April 2009.

4. Jiang Rong, Le Totem du Loup, p. 248.

5. Ibid, p. 196.

6. See Chapter 27, Le Totem du Loup, p. 436-447.

7. See Wolfgang Kubin on Contemporary Chinese Literature, ESNW Culture Blog, http://zonaeuropa.com/culture/c20061214_1.htm, accessed 20 April 2009

8. See L'Express, 10 January 2005, http://www.lexpress.fr/actualite/monde/asie/loupsetdragons_487398.html, accessed 20 April 2009.

\section{AUTHOR}

\section{NOËL DUTRAIT}

Professor of Chinese Language and Literature at the University de Provence, France. 